\title{
Public policies and multilevel governance to promote the creative economy from the cultural field: inter-federative support for Curitiba's policy
}

Políticas públicas e governança multinível para promover a economia criativa a partir do campo cultural: suporte interfederativo para a política de Curitiba

\author{
Mario Procopiuck (1) \\ Schirlei Mari Freder (2) \\ (1) Pontifical Catholic University of Paraná \\ (2) FAE University Center
}

\begin{abstract}
The design and implementation of public policies to promote the creative economy as a new sustainable development based have not shown the same results in different societies. This article aims to evaluate the strength and ability of a multilevel governance system formed by institutions and actors at federal, state, and local levels to design and implement public policy to promote the creative economy as an alternative for Brazilian development. The analysis is guided by the concept of multilevel governance, considering horizontal relations and vertical relations to address the public problems of interest to all. The processmapping model for the formulation of public policy called Multiple Streams was necessary for its potential to grasp the logic of the political process. The results indicate the difficulties in forming a multilevel governance system with sufficient capacity to design and implement public policies from the cultural field to promote the creative economy at the federal level, in the state of Parana and the city of Curitiba.
\end{abstract}

\section{Keywords}

Development policy, creative economy, public policy for culture, sustainable development, urban development.

JEL Codes O1, O14, O19, Z1, Z18.

\section{Resumo}

O design e a implementação de políticas públicas para promover a economia criativa como uma nova base de desenvolvimento sustentável não têm mostrado resultados semelhantes em diferentes sociedades. Este artigo tem como objetivo avaliar a força e a capacidade de um sistema de governança multinivel brasileiro formado por instituições e atores nos niveis federal, estadual e local para conceber e implementar politicas públicas para promover a economia criativa como uma alternativa para desenvolvimento. A análise é orientada pelo conceito de governança multinivel, considerando as relações horizontais e as verticais para abordar os problemas de interesse público relacionados à institucionalização da economia criativa. O modelo Múltiplos Fluxos foi necessário para o mapeamento de processos para a formulação de políticas públicas. Os resultados indicam as dificuldades par formar um sistema de governança multinivel com capacidade suficiente para projetar e implementar políticas públicas do campo cultural para promover a economia criativa no nivel federal, no estado do Paraná e na cidade de Curitiba.

\section{Palavras-chave}

Economia criativa, governança multinivel, políticas públicas, modelo multple streams.

Códigos JEL O1, O14, O19, Z1, Z18. 


\section{Introduction}

Recently, the search for ways to promote the creative economy as a new basis for more sustainable development has occupied the agenda of many governments, and national and international organizations. In this way, countries, regions, and localities are focusing on reducing pressure on natural resources based on the increased use of intangible assets (originated in culture, knowledge, and technology associated with creativity), to satisfy human needs. For example, a study by the Federation of Industries of Rio de Janeiro (FIRJAN 2014) found that the creative industries generate $2.6 \%$ of Brazil's \$2.2 trillion GDP and that, during the last decade, this industry grew $69.8 \%$ in relation to GDP, which grew $36.4 \%$. Faced with promising results like these, the creative economy might provide a new perspective to revitalize traditional industries and open spaces to new sectors, while mainly being based on the intensive use of knowledge and creativity whose generation and application can be stimulated by planned urban contexts for the development of creative classes and activities (SCOTT 2006; LEVICKAITÈ 2011).

However, many countries still face difficulties in designing and implementing public policies to promote development perspectives different from those that stimulate only the growth of the traditional economy that is heavily dependent on the use of natural resources. Contrary to these conservative tendencies, some governments, academics, and civil society actors are trying to innovate how to design strategies based on the use of the creative economy as a new perspective to more sustainable development. The discussions about these new development opportunities usually are around the highlighted themes of creative industries (LANGE and MIEG 2006; LANGE 2010; BERTACCHINI and BORRIONE 2011; FACHINELLI et al. 2013; CARDOSO et al. 2017), creative classes (HOYMAN and FARIC 2009; WILSON 2010; FLORIDA et al. 2011; BÁEZ et al. 2014; ZDEPSKI et al. 2018), and creative cities (HALL 2000; HOSPERS and PEN 2008; EVANS 2009; PRATT and HUTTON 2013; FREDER et al. 2018). Such themes have been addressed in the multidisciplinary and transverse mode, for example, in the areas of innovation, technology, economics, culture, entrepreneurship, sustainability, and urbanism (GARNHAM 2005; TAYLOR 2013; KACERAUSKAS 2015).

In Brazil, the discussion about the creative economy and the different 
possible perspectives to approach it is relatively recent (MIGUEZ 2007a; COSTA and SOUZA-SANTOS 2011; PROCOPIUCK e FREDER 2013; 2014; MELO and PAIVA 2016). In the practice field, the federal government, through the Ministry of Culture, began a series of programs and actions in 2011 to promote and encourage the creative economy, centered on culture. Based on a different conception of the creative economy, these government actions have focused on promoting discussions involving a variety of actors linked to different spheres of government and civil society, as well as on the financing of local entrepreneurs and academic research initiatives that deal with creative activities.

In this context, this article aims to evaluate the solidity and capacity of a multilevel governance system formed by institutions and actors at federal, state, and local levels to design and implement public policy to promote the creative economy as a national, state, and municipal development alternative for Brazil. The study evaluates the multilevel governance system in which actors from the federal government, the Paraná state government, and the Curitiba County government advocate a public policy to promote the creative economy in each of these levels of the Brazilian federation. The question that motivated this research is whether strategies for designing and developing public policies to promote the creative economy in Brazil are effective or whether they are developing regardless of federal, state, or local actions.

\section{Economic relations and development}

In the course of changes in society, the emergence of movements or events that cause structural changes at certain times has not been unusual, as happened in the economic field with the Industrial Revolution. In this historical moment, the relations of production experienced profound changes, and the process of urbanization intensified dramatically. Initially, the production of goods by artisanal processes was changed to highly labor-dependent industrial processes involving natural resources and salaried manual labor in fragmented activities of relatively low complexity. Historically, this industrialization system has increased the level of dependency of the national development strategies, especially when seeking to maintain good standards of living in cities. In recent decades, the discussions around 
the limitation of capacity development based on this model became more intense, mainly because of the limited availability of natural resources and because of the negative externalities that such industrial structures have generated for urban quality of life.

These changes has required the historical undervaluation of intangible resources such as culture to be revised, and consequently led to the refutation of some points of classical economic thought, for example, that of Adam Smith (1723-1790). This economist understood that economic activities related to culture, art, and entertainment were not important to the generation of wealth because such activities are manifested in the market in the form of services, which are not able to add value in production chains. The rationale for this was that the economic value would be lost because of the lack of a base material that would allow the transfer of value to other stages of the production chain (PROCOPIUCK and FREDER 2014, p.299). The refutation of assumptions like these has allowed the emergence of a new spirit of capitalism, which arises from the transition from an accumulation model dependent on a material basis for value retention to models that allow for the generation of economic value based on the immateriality of informationalism (PIRES and ALBAGLI 2012, p.112), which has typically been called cognitive capitalism (DE ANGELIS and HARVIE 2009; DHAOUI 2013). From a broader perspective, this means that both the value flow in internal production chains and the generation of value for national economies become more dependent on largely intangible goods and services, i.e., those that are less dependent on material resources.

These changes in the means for generating and adding economic value and the emergence of new forms of economic relations led to the "New Economy," which is based on the generation of knowledge-based wealth (HEALY 2002; MORISET 2003). In this new scenario, the intangible dimension overlaps with the base material traditionally used to generate wealth from the production of goods and services. Efforts shall, therefore, be undertaken to create economic value from the human potential motivated by ethical and cooperative contexts that stimulate creativity (PINHO 2011, p.26-57). In this sense, social, political, and market movements have occurred intensively in several countries aimed at seeking alternative ways to rebuild the economy of cities that historically have been dependent on the traditional industry. New strategies are being designed to ensure 
conditions that encourage job creation based on the intensive application of knowledge, technology, culture, and creativity (ASKERUD 2008, p.235236; FACHINELLI et al. 2013; COLES 2015).

In this context, the endogenous development from activities based on the principles of the new economy and the creative economy point to promising possibilities for renewal of the economic dynamics of the city based on the revaluation of the creative capital associated with spaces and urban territories (SEIXAS 2011). The involvement of national governments and regional and local authorities has become essential in conducting this process of renewal (MOURA and PROCOPIUCK 2020), assuming a catalytic role for entrepreneurial initiatives that enhance the attraction of multiple actors to form a local base of creative human capital and solid foundations that allow the productive insertion of these workers into national and international markets (PIACENTI 2012, p.63-66).

Changing the profile of traditional production relations to the new economy requires that companies and governments be able to create strategies ranging from simple activities performed individually, for example, crafts, to highly complex activities, such as audiovisual production based on high-tech application and the joint work of hundreds of people. So, the challenge is in generating ability to design and implement strategies with sufficient amplitude to mobilize the largest number of people and sectors of society that can legitimize the creative economy as a strategic development base. Despite the efforts made so far, the levels of success in this direction have remained highly uneven among different nations.

\section{Creative economy}

The creative economy theme has been discussed more intensively since the 1990s (NEWBIGIN 2010, p.16; BÁEZ et al. 2014). However, for many experts, this issue is not new; it originated from the arts economy and cultural economy (MIGUEZ 2007a, p.98). Therefore, the creative economy would only be a natural attempt to categorize new economic sectors. So, when the discussions start from only the perspective of culture, strategies to generate economic value from cultural activities do not cease to be controversial. The following discussion seeks to explain these relationships and confront them with the assumptions of the creative economy guided by broader 
perspectives than those traditionally developed in the field of culture.

The first discussions on the creative economy guided by cultural assets emerged in Australia in 1994, when the government hired experts to initially develop a plan with strategies to increase the use of intangible assets as a source of national competitive advantage, able to insert that country as an important player into the new global economy. This initiative resulted in the publication of the report "Creative Nation," as a proposal to make the country one "Creative Nation" (MIGUEZ 2007a, p.99). The government proposal was aimed at developing a cultural policy to reposition the state's economic role in the cultural development of the country and vice versa. Subsequently, in that country emerged the first educational and research institutions on the creative economy and creative industry and, consequently, the first in-depth theoretical and conceptual discussion about this topic. The Queensland University of Technology (QUT) now hosts a "Creative Industries Faculty." In this college, located in Brisbane, was created the research center called "The Institute for Creative Industries and Innovation" (ICI) (MIGUEZ 2007b, p.5).

In 1997, the creative economy theme started to gain traction also in the UK, which was experiencing economic problems. Based on the creative economy, specifically through the creative industries, strategies were envisioned for the economic restructuring of urban centers, especially those most affected by the decline of the traditional economy. In a document prepared in 1998 by the Department for Culture, Media and Sport (DCMS), the concept of the creative industry was developed to cover activities based on culture, communication, design, and information technology. The assumption was that all these activities had strong links with creativity and, thus, could represent a dynamic sector of the country's economy. Therefore, this sector should be recognized by the state as an area that would increase the other economic sectors (DE MARCHI 2014, p.197-198).

In 2001, Howkins published a book using practical experience to defend the notion that there are strong links between the economy and creativity, explaining the nature, extent, and ways in which these two dimensions can be combined into economic systems to create extraordinary value and wealth. Unlike, therefore, in classical thought, creativity was seen as having the potential to generate goods or services, which the author calls creative products. The intensification of creativity in artistic activities, scien- 
tific discoveries, innovations in research and development, and innovation processes and business institutions created concerns about protecting intangible creations as intellectual property, e.g., such as copyrights, patents, trademarks and industrial designs (HOWKINS 2013, p.12-21).

These implementation experiences of development policies based on the creative economy, as well as the theoretical discussions about the new perspectives brought by this issue, show more than simple attempts to use culture instrumentally to add value to products and services. The creative economy presupposes a proper perspective that allows, concomitantly and interactively, culture, knowledge, technology, and creativity to be addressed to generate new products and services with sufficient amplitude to enhance the development of nations, and not simply sectors or industries.

\section{Methodology}

Analytical strategies to evaluate public policies vertically and horizontally are essential to understand how public bodies and private and third-sector organizations behave in the development of these policies at different levels, especially in federal systems like Brazil's. In this case, analysis guided by the concept of multilevel governance can be particularly promising for allowing us to consider strategies to implement public policies that simultaneously involve the federal, state, and municipal governments, considering horizontal relations (between actors located in the same level of the federation) and vertical relations (between actors located in the municipal, state, and federal levels) to address the public problems of interest to all (PROCOPIUCK 2013, p.181-182).

For this, the process-mapping model for the formulation of public policy, called Multiple Streams, developed by John W. Kingdon (2014), may be necessary for its potential to grasp the logic of the political process. In this model, three different streams develop independently, but complementarily, and are essential in the policy-making process. In the problems stream, there is recognition, identification, and explicit definition of the problem that will be the object of attention and generate pressure to be solved by government action. The politics stream, according to the dynamics and rules of politics, develops naturally in conflicts and changes of government actors, permeated by bargains and dependent on political 
negotiating moods and partial agreements to adjust interests of pressure groups, which can lead to the adoption or exclusion of alternatives or solutions. The policy stream is a process that develops persuasively and interactively to generate and select a limited set of alternatives or solutions considered most relevant for the community policy. The convergence of these three streams to create a window of opportunity is called a policy window, for coupling of such streams is dependent on the performance of political entrepreneurs who support political connections through negotiations. In the formulation of public policy, a set of processes develops, including a) the definition of an agenda, b) the alternative specification for policy choices, c) the authorized choice between the specified alternatives, and $d$ ) implementation of the decision (KINGDON 2014). Through the combination of this stream with the process of implementation of public policies in a multilevel governance structure, such as that of Brazil, the base model of this research was obtained (Figure 1).

Figure 1 Conceptual Model used for research

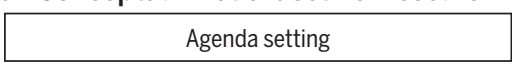

Policy implementation

흥
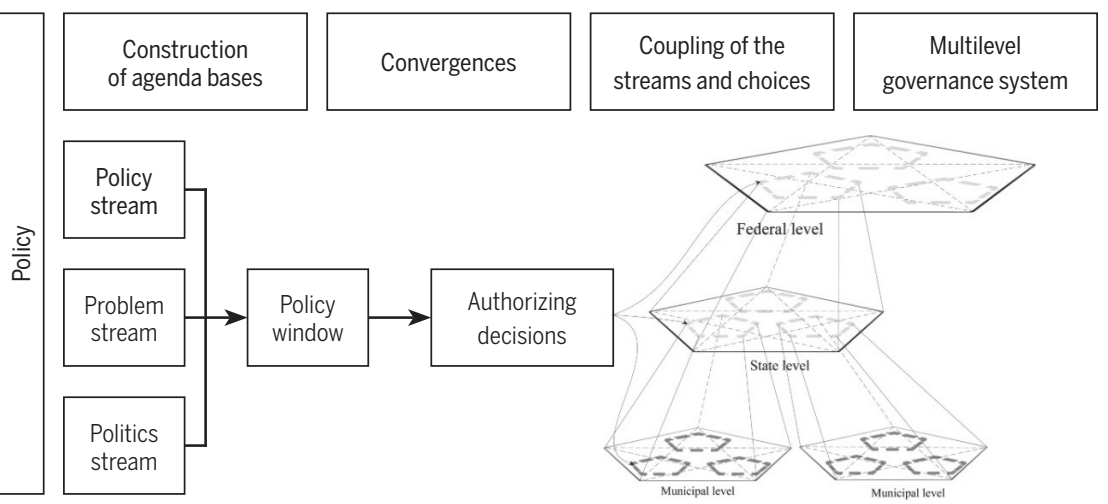

Entrepreneus

Source: Integration of Kingdon (2014), Procopiuck (2013), and Lenton \& Allsop (2010) models.

The model shown in "Figure 1" helps us in understanding the relationship between the three units of the Brazilian federation (union, states, and municipalities) from a procedural and multilevel perspective and the different stages through which the choices passed, and it thus helps us to under- 
stand the development of public policy to promote the creative economy. This model allowed us to analyze the most significant relationships that have influenced the development of the creative economy in Curitiba.

In the first phase of research, the data were collected through document analysis, which was complemented in the second with interviews, totaling 5 hours and 47 minutes of recordings, with representatives of Secretaria da Cultura, Rede de Economia Criativa do Paraná, Movimento Curitiba Criativa, Agência Curitiba de Desenvolvimento, Fundação Cultural de Curitiba e Comissão de Urbanismo da Câmara Municipal de Curitiba.

\section{Presentation and analysis of results}

Based on obtained qualitative data and a methodological approach, the discussion was organized on a top-down basis, starting with findings on the logic of development of public policies at the federal level, through the State of Paraná, to, finally, an evaluation of how this occurred in Curitiba.

\subsection{Development agenda and public policy at the federal level}

Gradually, the creative economy began to arouse global interest and was put on the agenda of international organizations. For example, in São Paulo in 2004, the United Nations Conference on Trade and Development (UNCTAD) decided that the thematic creative economy would be treated at UNCTAD XI. On that occasion, analysis, research, and promotion of international actions have been intensified by the international organizations to support the redefinition of public policies to aid countries to diversify their economies by promoting the cultural and creative sector. As a result, Brazil became aware of these questions (SANTOS-DUISENBERG 2012, p.76). Since then, the UNCTAD published two reports presenting research, statistics, and indicators on the creative economy from a global perspective: "Creative Economy Report 2008: The challenge of assessing the creative economy towards informed policy-making" was published in 2009, and the "Creative Economy Report 2010 - Creative Economy: a feasible development option," in 2011.

In this context, at the federal level, the public policy for the develop- 
ment of the creative economy, the problems, politics and the policy stream showed signs of convergence based on discussions on the creative economy that occurred in different national (MIGUEZ 2007a; REIS 2008) and international spheres (UNCTAD 2010), and advances in the production of evidence of the importance of the creative economy in the national context (FIRJAN 2008; CAIADO 2011). At the federal level, Law No. 13,243, published on December 2, 2010, was regarded as the "birthplace of the institutionalization process of cultural policies in the area of the creative economy, specifically in the cultural economy field" (BRASIL 2011, p.39).

The creative economy theme formally entered the Brazilian federal government's agenda when it was officially located in the field of public policy culture. Consequently, the assignments to design and structure a public policy were placed under the Ministry of Culture (BRASIL 2011, p.19-20). As a means of political and administrative support, the Secretariat of the Creative Economy (SCE) was defined by Decree No. 7743/2011. The mission of SCE was one of "leading the formulation, implementation and monitoring of public policies for local and regional development, giving priority to the support and development to professionals and micro and small Brazilian creative endeavors" (SEC 2013, p.8). Subsequently, the team to develop the Brazil Creative Plan was named. The result was the "Secretariat of the creative economy plan: Policies, guidelines, and actions, 2011-2014," which redefined important aspects of the role of culture in Brazil. This document, designed to serve as a reference on the policy of the creative economy in Brazil, had difficulty defining the concept "creative industry" in Portuguese. Therefore, the concept "creative sector" was conceived as originating in the cultural sector. It was possible to differentiate the creative sector from other economic sectors. In terms of general guidelines, this derivation limited the sector concept to mainly cover cultural activities, making it difficult to embrace actors and segments of society interested in discussions about creativity linked to technology, knowledge, innovation, entrepreneurship, sustainability, and urbanism.

In terms of practical application, while seeking to involve other ministries in efforts to foster the development of the creative economy, the SCE participated in actions carried out by civil society organizations and the online discussion networks (the Creative Economy Network, which was formed by a group of São Paulo and Paraná stakeholders; discussion forums; etc.), and in other activities carried out by organizations linked 
to the market (private educational institutions that now promote courses and other initiatives). The efforts were directed at forming the basis of a public policy issue of broad interest from different sectors of society, represented by the need to institutionalize a policy of incentives to the creative economy also at the state and municipal levels. Back then, promising prospects were opened with adjustment budget allocations of the Ministry of Culture to be applied to programs and projects related to the creative economy. It was possible to enable several initiatives in a short time. Such initiatives include the creation of observatories, the implementation of the Creative Bureaus, and publishing public calls to fund research and awards.

Although important in terms of institutionalization of the administrative apparatus to support the development policy of the creative economy, the choice of the field of culture for the implementation of the creative economy raised questions, for example on the conceptual foundations that guided the decision on which creative industries compose the scope of Brazil's Creative Plan and the institutional capacity of the Ministry of Culture to implement the public policy of the creative economy. According to Pavanelli (2013), an alternative would be to implement more institutionalized policies for the creative economy, so that they became favorable to inter-ministerial action. This could occur through the allocation policy coordination at the Civil House (Executive Office), directly subordinate to the Presidency. The justification was that this department with ministerial status would be closer to the Presidency. Consequently, there would be more independence and political force for coordination with other ministries and representatives of the various creative sectors involved, following the model adopted in the UK.

Notwithstanding the weaknesses in institutional arising from positioning on equal political and administrative capacity concerning other ministries, the Ministry of Culture, from the steps of the formation of the agenda, tried to coordinate with 20 ministries operating in areas of policy interest to promote the creative economy. To this end, representatives of 16 ministries took part in a meeting held on May 16, 2011. The meeting was part of the identification process interfaces between the policies of ministries and the SCE action axes (SEC 2013, p.21-36). In the case of the field of tourism, intentions to carry out cross-cutting actions with other public policies were declared, in recognition of the importance of cultural tourism. In terms of incentives, which depended on isolation from 
the Ministry of Culture action, several public calls for awards, support for training programs, and support for the implementation of incubators and cultural contests were made possible (SEC 2013, p.37-43). There are also reports on institutional partnerships with national and international organizations, such as participation in committees and signing of terms of cooperation (SEC 2013, p.43-47).

During the period analyzed in this research, intensive efforts to add the creative economy to the government agenda have been identified, which created conditions favorable to institutionalizing the Brazilian federal administrative system, including allocating specific budget resources to cover specific initiatives. However, despite the quick internal restructuring of the Ministry of Culture-so that there was the expertise of an administrative apparatus of support and political discourse for allocation of budgetary resources-efforts were restricted to the activities of the Ministry of Culture and some external political entrepreneurs. It is noteworthy that despite the involvement of external actors, such efforts to create alternatives to implementing a creative economic policy have not involved major institutional actors under the authority of the Ministry of Culture, for example, the National Council of Culture, the National Arts Foundation (FUNARTE), the National Cinema Agency (ANCINE), and the Institute of Historical and Artistic Heritage (IPHAN). This strategies demonstrates that, due to its low capacity for internal and external coordination, the SEC has played more of a bureaucratic role in the Ministry of Culture and less the role of a strategic institutional actor in designing and implementing a comprehensive and sustainable public policy meant to promote the creative economy from the cultural field in Brazil.

The institutional weakness associated with the difficulty in defining the concept of a creative economy and creative sector to strongly link the cultural sector with the most innovative creative activities may partly explain the reduced intensity of the efforts to implement the policy to promote the creative economy, which the federal government initiated after 2012. In 2015, the Creative Economy Secretariat was abolished within the same government that created it. So, in terms of institutionalization, the creative economy failed to become state policy. It was restricted to government policy, with populist nuances. More seriously, with the extinction and recreation of the Ministry of Culture in 2016 by the provisional government, the relatively low development of the creative economy development pol- 
icy in Brazil tended to recede dramatically. Therefore, considering that the cycle of failed attempts to institutionalize public policy was completed, the question of the creative economy in Brazil returned to the early stages of the public policy cycle and became dependent on the emergence of new political entrepreneurs who could find new windows of opportunity in the political field to try to advance the development of public policy in order to promote it.

\subsection{Development agenda and public policy at the State of Paraná level}

At the state level, initiatives and discussions related to the theme of the creative economy in Paraná arose in late 2011, when the theme was also in evidence on the agenda of the federal government. The majority of actions were concentrated in the state capital, Curitiba, and strongly linked to the field of culture, as well as to what was happening at the federal level. Among the stakeholders who took part in the discussions on the creative economy, there were representatives of government agencies, civil society organizations, and educational institutions.

The leadership of the process for the institutionalization of the creative economy as public policy was the Secretary of State for Culture (SEEC), since 2011. On November 9-10, 2011, the first state event on the creative economy, called "Economy Seminar Creative," was held, which 321 participants attended. Organized and promoted in partnership with the Secretary of State for Tourism (SETU) and department of culture of the Service Social Industry (SESI-PR), it took place in Curitiba, in the Oscar Niemeyer Museum, and aimed to promote awareness about the importance of the issue. It was attended by key players in setting the government agenda at the state and federal levels, as well as researchers and professionals (SEEC 2011, p.2-10; 11-54; 24). Among the other regional and state-level actors were highlighted the Network of Paraná Creative Economy, the Federal University of Paraná, and Innovation Agency of the Federal University of Paraná, which have held events, seminars, and thematic meetings in Curitiba and the state's coast.

In October 2012, the Innovation Agency of the Federal University of Paraná organized the "I - Seminar Creative Economy: what are we talk- 
ing about?". Participants were mainly in the arts and cultural sectors and included officials from local, state, and federal governments. On that occasion, the representative of the Ministry of Culture, Mercia Queiroz, explained the model of operation of the Observatories of Creative Economy, which would work in the states in partnership with federal universities and the National Observatory linked to the Ministry of Culture. The representative of the Ministry of Culture suggested the Federal University of Paraná host the observatory of Paraná. It was not possible to observe the unfolding of this issue in practical terms to end the data collection for this research.

A government initiative to bring forward the policy of encouraging the creative economy has not advanced. In this sense, it is interesting that, although the discussions on the development policy of the creative economy in the state of Paraná have been conducted in the field of culture, at no time was the participation or involvement of the State Council of Culture, established in 2012, mentioned. The Council has the responsibility of "overseeing the implementation of cultural projects and the application of funds, issuing opinions on technical and cultural issues, participating in the formulation of public policy of the State Government in the area of culture, encouraging the protection of cultural heritage, enhancing cultural events local and regional, encouraging research on the culture of Paraná, among other important actions" (PARANÁ 2012). According to one of the respondents, although the government planned the creative economy theme, it had not distributed funds for investments in projects or programs that showed real intentions to realize what had been planned. Thus, in practical terms, beyond the few discussions that took place in Curitiba, it was not possible to identify actions aimed at generating results in terms of local or regional development in any of the 399 municipalities in the State of Paraná.

At the state level, based on field observations, it was found that the process of forming an agenda for the creative economy was in the first deployment phase. Based on the model of multiple streams, one of the few initiatives that advanced was the attempt to implement the Creative Bureau, through a partnership of state and federal agencies. As for stream problems, the strategy was to increase the level of awareness of social actors and local politicians through events organized by the State Secretariat of Culture, for example, lectures, courses, and workshops. The alternative stream passed the budget process and choice of infrastructure represented 
by the unsuccessful implementation of the Bureaus. The political stream was in favor of achieving consensus among different interest groups in Curitiba, but with no lasting consequences for the creative economy in other municipalities. These multiple streams opened a window of opportunity for interaction between federal and state political entrepreneurs. One result of this interaction was the signed agreement that formalized the government agenda intended to install the Creative Bureau in Curitiba. The announcement for the implementation of this project was made in July 2012. In October of that year, the cooperation proposal was forwarded, and in February 2013, it was signed with a commitment to the inauguration that took place in June 2014 (GUILHERME 2012). Even in 2013, the Ministry of Culture transferred a part of the covenant of the resources to be initiated as infrastructure projects. However, the installation of the Creative Bureau was paralyzed by the inability to succeed in bidding for the renovation of the building where it was installed.

\subsection{Development agenda and public policy at the Curitiba level}

In March 2012, the city of Curitiba started the "Movement Curitiba Creative." This movement was initiated by the Creativity School, which was a private-sector organization. This movement had the support of the local branch of the Brazilian Micro and Small Business Support Service (Sebrae) and the Paraná State Trade Federation (Fecomércio) for the preparation of a project to revitalize the commercial activities of the historic center of Curitiba. For a year, meetings were held with actors from different areas of the creative economy, in order to gather information about that historic center to devise initiatives and projects to develop the creative economy. After this first phase, from 2013, the meetings were paralyzed because there was no involvement of the municipal government, which would be critical to the implementation of some proposals (Interviewed PRJ). However, the Creative Bureau did not work because of the inability of the government to successfully bid for the renovation of the building where such an office was to be installed.

At the end of 2013, as the first action of the Curitiba municipal government, the conference called "Meeting of the culture and creative economy indicators inspirations for Curitiba," coordinated by the Curitiba Develop- 
ment Agency, was held. In mid-2014, two events were promoted by the Curitiba Cultural Foundation, together with the Curitiba Development Agency. The course "Culture \& Autonomy, a guiding plan for the future," was offered in partnership with the Brazilian Micro and Small Enterprises Support Service (Sebrae); and a lecture on "Creative Economy - Study and development of production processes linked to creativity and knowledge" was offered in partnership with the Federation of the State of Paraná (Fecomércio) and the Social Service of Commerce (SESC-PR).

In the sphere of the Municipal Executive, some intentions related to the creative economy were linked to the Government Plan 2013-2016, on the theme "Sustainable Development and Employment," which aims to "reposition Curitiba among the main innovative and creative cities in the world through appropriate incentives and funding instruments" (CURITIBA 2013a, p.29). From these guidelines have been established goals and projects set out in the Multiyear Plan (PPA) 2014-2017, which was developed based on four strategic dimensions: Quality Urban and Environmental, Economic Development, Social Development, and Participatory Governance (CURITIBA 2013b). The Municipal Legislature in May 2014 promoted a Public Hearing to deal with the community under the theme "Creative and Cultural Economy." The audience composed a set of Curitiba City Council initiatives in the review process of the Director of Curitiba Plan.

As at the state level, the Municipal Culture Council did not take part in actions to promote the creative economy, especially in the events that occurred in the context of public cultural policies. By the end of the research, other actions at the local level were not identified, either at the government or civil society level, which could demonstrate the formation of a specific agenda for public policy formulation to promote the creative economy in the city. The creative economy has appeared only as a secondary theme in the government plan and urban planning process of Curitiba, which shows weakness in its institutionalization.

Based on the application of the multiple-streams model, in Curitiba, the evidence shows that not all streams came to be triggered, which shows a process at an early stage. Indicia of the relevance of stream problems can be verified by the events, meetings, and lectures. The stream of alternatives showed evidentiary choices that were part of the government plan and multiyear plan. The political stream was evidenced mainly by the apa- 
thetic attitude of public officials about the creative economy. In the case of Curitiba, developed political actions were not enough to make the creative economy a strategic issue for the city. Windows of opportunity were envisioned by public and private actors, but without these actors could put the promotion policy to the creative economy with a prominent element on the agenda of the municipal government.

In the case of Curitiba, the governmental and civil society organizations with core functions in the local public policy formation process still seek to understand how the creative economy could contribute to local development. Past this phase, perhaps with greater involvement of actors belonging to the local market, there may be more substantive proposals on how to promote the creative economy beyond the current preliminary stages. Perhaps the decision-makers have been unable to mobilize forces or develop interest, or did not realize the opening of the window of opportunity so that they could consistently progress in the formulation of public policy in this direction to the city.

\section{Conclusions}

At the federal level, the institutionalization strategy of the creative economy, meant to put the country on a path more in line with the new economy, seems to have thrived in the field of culture. In this field, there was some confusion between the fundamentals of the creative economy, the cultural economy, and social integration policy, which limited the possibility to design more comprehensive public policies that allowed the stimulus to open spaces for working-for example, ecosystem creativity in cities associated with innovation in technology parks and encouragement for the development of high technology with a focus on the valuation of the intangible dimension of products and services. In this sense, the cultural sectors of federal, state, and municipal governments have not shown sufficient institutional capacity to coordinate among the different actors to form a multi-level and sufficiently comprehensive governance system to support a broad development policy on the more sustainable basis of the creative economy.

At the state and municipal levels, the development policy to the creative economy in Paraná and Curitiba also showed weaknesses. In Paraná, 
it has not yet been possible, for example, to establish a program or project to promote the creative economy statewide, although efforts to do so began in 2011. The lack of interest in this issue is showed by the absence of initiatives, for example, initiatives seeking to allocate specific budgetary funds to stimulate new regional development based on the principles of the creative economy. In the case of Curitiba, despite actions planned in the Curitiba Creative Program, part of the Multi-Year Plan, the governmental actions have not yet passed the discussion stage to define what the creative economy actually is. So, without consensus-building on what can be covered by the creative economy, large enough difficulties remain to allow a glimpse of the possibilities of getting practical results that demonstrate the government's ability to promote the creative economy. Just as at the federal and state levels, at the municipal level, the actions of official institutions were limited to meetings and events to raise awareness through discussions on how to advance municipal development based on the creative economy. No practical results indicate that the creative economy is a strategic priority for the municipality.

The political and administrative coordination between the federal government, the state government, and the municipal government have not demonstrated a strong enough multilevel governance structure to legitimize and strengthen the relationship between government actors to form an agenda for establishing public policies that promote the creative economy associated with sustainable development possibilities. This stems from the lack of clear definitions of the scope and potential of the creative economy. In summary, it shows that these actors are not dealing with common problems or are willing to work with a public policy that is a distinct sectoral policy, as classical economics of culture. Evidence of this is that departments or advisory government bodies tend to deal with specific projects and are isolated; most of them without involving key actors within the government structure responsible for managing the area of culture. This lack of involvement is found, for example, in the absence of Culture Councils in the state and the municipality, and the National Arts Foundation (FUNARTE), National Cinema Agency (ANCINE), and the Heritage Institute for National Artistic (IPHAN) in the national context. The few initiatives developed jointly by representatives of all three levels of government were not more than initial projects aimed at raising awareness about the importance of the creative economy, so there is still 
no potential to generate results with impacts on the local, regional, or national economies.

Therefore, in Brazil, it is possible to conclude that the government's development of the creative economy has not advanced sufficiently beyond plans of governments to the formation of a public policy of the state. In contrast, market actors have not yet emerged who explicitly defend the value of this new perspective to leverage their businesses. In the field of organized civil society activity and representative segments of trade and industry organizations, there have been greater efforts to prove the importance of the creative economy in adding value to the local, regional, and national economies. This context allows us to answer the initial question that asks whether, if the creative economy develops at a fast pace in Brazil, as indicated by the statistics on economic activities, there is more reliance on individual entrepreneurs' initiatives than on the government's ability to promote initiatives to leverage more solid foundations for sustainable development in more innovative perspectives. This context shows that - relying on the government's demonstrated capacity for action - Brazil's economic development will continue to be highly dependent on traditional activities involving the intensive use of natural resources, thus aggravating the current environmental problems, such as deforestation, gas emissions, and, consequently, global warming.

The absence of a specific state public policy, as there was only one public government policy, placed the creative economy in Brazil as an issue with low relevance in the programs of the different governments. In federal government systems, such as the Brazilian one, there are significant challenges for the structuring of multilevel governance systems based on actions originated and articulated only internally to the Executive Branch. The difficulties arise because the Executive Branches of the Union, States, and Municipalities are governed by politicians and administered by managers linked to different political-ideological tendencies, which creates difficulties in defining common interests and reaching agreements to maintain them. Therefore, reaching consensus between these three levels presupposes the need for public policies regulated by legislation emerging from parliamentary debates at the federal level. These parliamentary debates would make it possible to obtain the representation of the States of the Federation and, consequently, of the municipalities from the territorial bases of the elected deputies. However, if, on the one hand, the absence of a rigid multilevel 
governance structure may represent a restriction on the functioning of public policies, such as the national diffusion of the creative economy in Brazil; on the other, freedom and the capacity for local and regional initiative allowed the autonomous development of the creative economy to continue, based on local resources and interests. The importance of this relative autonomy is evident at times like the present when the Ministry of Culture was extinct in 2019 and, consequently, the Federal Government's Creative Economy policy. Although this extinction had adverse effects on actions at the federal level, it did not significantly interfere with the autonomous actions of states and municipalities, where the creative economy continues to develop promisingly in some regions and cities.

\section{References}

ASKERUD, P. As indústrias criativas: perspectivas da região da Ásia-Pacífico. In: REIS, A.C.F. (Org.). Economia criativa como estratégia de desenvolvimento: uma visão dos países em desenvolvimento. São Paulo: Itaú Cultural, 2008.

BÁEZ, J.M.;BERGUA, J.A.;PAC, D. The Creative Class and the Creative Economy in Spain. Creativity Research Journal, v.26, n.4. p.418-426. 2014. D.O.I: 10.1080/10400419.2014.961769.

BERTACCHINI, E. E.; BORRIONE, P. The Geography of the Italian Creative Economy: The Special Role of the Design and Craft-based Industries. Regional Studies, v.47, n.2. p.135147. 2011. D.O.I: 10.1080/00343404.2011.628652.

BRASIL. Plano da Secretaria da Secretaria da Economia Criativa: políticas, diretrizes e ações, 2011 2014. Brasília: Ministério da Cultura, 2011.

CAIADO, A. S. C., (Org). Economia criativa: economia criativa na cidade de São Paulo - diagnóstico e potencialidade. São Paulo: Fundap, 2011. 160 p.

CARDOSO, E. L.; PRODANOV, C. C.; DORION, E. C. H.; NODARI, C. H.; CHAIS, C. Análise do setor audiovisual do sul do Brasil sob a perspectiva da inovação. Nova Economia, v.27, n.2. p.185-211. 2017.

COLES, A. Creative class politics: unions and the creative economy. International Journal of Cultural Policy, v.22, n.3. p.1-17. 2015. D.O.I: 10.1080/10286632.2014.994612.

COSTA, A. D.; SOUZA-SANTOS, E. R. Economia criativa: novas oportunidades baseadas no capital intelectual. Revista Economia \& Tecnologia, v.7, n.2. p.1-8. 2011.

CURITIBA. In: PREFEITO (Ed.) Plano de Governo 2013-2016. Curitiba: Prefeitura Municipal de Curitiba, 2013a. https://www.transparencia.curitiba.pr.gov.br/.

CURITIBA. In: (Ed.) Plano Plurianual de Curitiba: saúde, educação e mobilidade são prioridades. Curitiba: Prefeitura Municipal de Curitiba, 2013b. http://www.curitiba.pr.gov. br/noticias/saude-educacao-e-mobilidade-sao-prioridades-no-plano-plurianual-de-curiti$\mathrm{ba} / 30776$. 
DE ANGELIS, M.; HARVIE, D. 'Cognitive Capitalism' and the Rat-Race: How Capital Measures Immaterial Labour in British Universities. Historical Materialism, v.17. p.3-30. 2009.

DE MARCHI, L. Análise do Plano da Secretaria da Economia Criativa e as transformações na relação entre Estado e cultura no Brasil. Revista Brasileira de Ciências da Comunicação, v.37, n.1, p.193-215. 2014.

DHAOUI, E. Cognitive Capitalism: Foundations, Assessment and Evaluation of New Perspectives. Journal Of Humanities And Social Science, v.11, n.2. p.71-78. 2013.

EVANS, G. Creative cities, creative spaces and urban policy. Urban Studies, v.46, n.5-6. p.1003-1040. 2009.

FACHINELLI, A. C.; JAVIER CARRILLO, F.; D'ARISBO, A. Capital system for creative economy and social innovation: A brazilian case. Proceedings of the $6^{\text {th }}$ Knowledge Cities World Summit (Kows 2013). p.472-484. 2013.

FIRJAN. A cadeia da indústria criativa no Brasil. Rio de Janeiro: Federação das Indústrias do Estado do Rio de Janeiro, 2008.

FIRJAN. Mapeamento da indústria criativa no Brasil. Rio de Janeiro: Federação das Indústrias do Estado do Rio de Janeiro, 2014. 40 p.

FLORIDA, R.; MELLANDER, C.; ADLER, P. The creative class paradigm. In: ANDERSSON, D.E., et al. (Org.). Handbook of Creative Cities. Cheltenham: Edward Elgar Pub., 2011. p.5671. Acesso:http://books.google.com.br/books?id=L1Oj-eFrer8C.

FREDER, S. M.; PROCOPIUCK, M.; AZZULIN, M. B. Patrimônio cultural polonês: contribuições para o desenvolvimento das cidades criativas Polonicus, v.IX, n.1. p.137-153. 2018.

GARNHAM, N. From cultural to creative industries: An analysis of the implications of the 'creative industries' approach to arts and media policy making in the United Kingdom. International Journal of Cultural Policy, v.11, n.1. p.15-30. 2005.

GUILHERME, L. L. Paraná vai receber o Criativa Birô. 2012.

HALL, P. Creative cities and economic development. Urban Studies, v.37, n.4. p.639-649. 2000. D.O.I: $10.1080 / 00420980050003946$.

HEALY, K. What's new for culture in the new economy? The Journal of Arts Management, Law, and Society, v.32, n.2. p.86-103. 2002. D.O.I: 10.1080/10632920209596967.

HOSPERS, G. J.; PEN, C. J. A View on Creative Cities Beyond the Hype. Creativity and Innovation Management, v.17, n.4. p.259-270. 2008. D.O.I: 10.1111/j.1467-8691.2008.00498.x.

HOWKINS, J. Economia Criativa: como ganhar dinheiro com ideias criativas. São Paulo: M. Books do Brasil Editora, 2013.

HOYMAN, M.; FARIC, C. It takes a village: A test of the creative class, social capital, and human capital theories. Urban Affairs Review, v.44, n.3. p.311-333. 2009.

KACERAUSKAS, T. Technologies in creative economy and creative society. Technological and Economic Development of Economy, v.21, n.6. p.1-14. 2015. D.O.I: 10.3846/20294913.2015.1036325.

KINGDON, J. W. Agendas, Alternatives, and Public Policies. Harlow: Pearson, 2014.

LANGE, B. Beyond creative production networks. The development of intra-metropolitan creative industries clusters in Berlin and New York City. Zeitschrift Fur Wirtschaftsgeogra- 
phie, v.54, n.2. p.140-142. 2010.

LANGE, B.; MIEG, H. A. Professionalization paths and the constitution of, markets" in creative industries. Geographische Zeitschrift, v.94, n.4. p.225-242. 2006.

LENTON, S.; ALLSOP, S. A tale of CIN—the Cannabis Infringement Notice scheme in Western Australia. Addiction, v.105, n.5. p.808-816. 2010. D.O.I: 10.1111/j.1360-0443.2010.02913.x.

LEVICKAITÈ, R. Four approaches to the creative economy: general overwiew. Business, Management and Education, v.9, n.1. p.81-92. 2011.

MELO, G. B. V.; PAIVA, G. L. Desenvolvimento e potencial de clusters criativos para as cidades médias brasileiras. Nova Economia, v.26., n. especial, p.1287-1316. 2016.

MIGUEZ, P. Economia criativa: uma discussão preliminar. In: NUSSBAUMER, G.M. (Org.). Teorias \& politicas da cultura: visões multidisciplinares. Salvador: EDUFBA, 2007a. p.95-113

MIGUEZ, P. Repertório de fontes sobre economia criativa. Salvados: Universidade Federal do Recôncavo Baiano, $2007 \mathrm{~b}$.

MORISET, B. The New Economy in the City: Emergence and Location Factors of Internetbased Companies in the Metropolitan Area of Lyon, France. Urban Studies, v.40, n.11. p.2165-2186. 2003. D.O.I: 10.1080/0042098032000123231.

MOURA, E. N.; PROCOPIUCK, M. GIS-based spatial analysis: basic sanitation services in Parana State, Southern Brazil. Environmental Monitoring and Assessment, v.192, n.2. p.96. 2020. D.O.I: $10.1007 /$ s10661-020-8063-2.

NEWBIGIN, J. The creative economy: an introductory guide. London: British Council, 2010.

PARANÁ. nº, de. Lei No 17.063 de 23 de janeiro de 2012. Publicação, de 2012.

PAVANELLI, R. TV Senado. In: (Ed.) Economia Criativa. Brasília, 2013. https://www.youtube. com/watch?v=clWGmtGU6Pk, 10/07/2014.

PIACENTI, C. A. O potencial de desenvolvimento endógeno dos municípios paranaenses. Curitiba: Camões, 2012.

PINHO, D. B. Aspectos da evolução da ciência econômica: do início do século XXI às raízes do pensamento econômico. In: PINHO, D.B., et al. (Org.). Manual de Economia v.6. São Paulo: Saraiva, 2011.

PIRES, V. S.; ALBAGLI, S. Estratégias empresariais, dinâmicas informacionais e identidade de marca na economia criativa. Perspectivas em Ciência da Informação. p.109-122. 2012.

PRATT, A. C.; HUTTON, T. A. Reconceptualising the relationship between the creative economy and the city: Learning from the financial crisis. Cities, v.33. p.86-95. 2013. D.O.I: http://dx.doi.org/10.1016/j.cities.2012.05.008.

PROCOPIUCK, M. Políticas públicas e fundamentos da administração pública: análise e avaliação, governança e redes de políticas, administração judiciária. São Paulo, 2013.

PROCOPIUCK, M.; FREDER, S. M. Políticas públicas de fomento à economia criativa: Curitiba e contexto nacional e internacional. Revista Brasileira de Planejamento e Desenvolvimento, v.2, n.2. p.15-29. 2013.

PROCOPIUCK, M.; FREDER, S. M. Economia criativa: modelo federal brasileiro e importância das discussões frente a referenciais internacionais. Cadernos do CEOM, v.27, n.40. p.227-251. 2014. 
REIS, A. C. F., (Org). Economia criativa como estratégia de desenvolvimento: uma visão dos países em desenvolvimento. São Paulo: Itaú Cultural, 2008. 267 p.

SANTOS-DUISENBERG, E. d. Secretaria da Economia Criativa no Brasil. In: Plano da Secretaria da Economia Criativa: políticas, diretrizes e ações 2011-2014. Brasilia, 2012. p.76-77.

SCOTT, A. J. Creative cities: conceptual issues and policy questions. Journal of Urban Affairs, v.28, n.1. p.1-17. 2006.

SEC. Relatório de ações da SEC 2011-2013. Brasília: 2013. Acesso:http://pt.slideshare.net/Catialu/relatrio-gesto-da-secretaria-de-economia-criativa.

SEEC. In: SEEC (Ed.) Relatório do Seminário de Economia Criativa. Curitiba, 2011.

SEIXAS, P. C. Urbanismo, cultura e globalização em Portugal: modelos analíticos e de desenvolvimento territorial. Revista Brasileira de Gestão Urbana, v.3, n.1. p.55-75. 2011.

TAYLOR, C. Between Culture, Policy and Industry: Modalities of Intermediation in the Creative Economy. Regional Studies, v.49, n.3. p.362-373. 2013. D.O.I: 10.1080/00343404.2012.748981.

UNCTAD. Relatório de economia criativa 2010: economia criativa, uma opção de desenvolvimento. São Paulo: United Nations Conference on Trade and Development, 2010.424 p.

WILSON, N. Social creativity: re-qualifying the creative economy. International Journal of Cultural Policy, v.16, n.3. p.367-381. 2010. D.O.I: 10.1080/10286630903111621.

ZDEPSKI, F. B.; GRIMM, I. J.; PROCOPIUCK, M. Aprendizagem expansiva e ecossocioeconomias na prática artesanal da Feira de Arte e Artesanato do Largo da Ordem em Curitiba-Pr. Revista da FAEEBA - Educação e Contemporaneidade, v.27, n.52. p.26-43. 2018.

\section{About the authors}

MarioProcopiuck -mario.p@pucpr.br

Graduate Program in Urban Management, Pontifical Catholic University of Paraná, Curitiba, Parana, Brazil; Graduate Program in Administration, Business School, Positivo University, Curitiba, Parana, Brazil.

ORCID: https://orcid.org/0000-0002-7346-1938.

Schirlei Mari Freder-schirlei.freder2@gmail.com

Visiting professor at Business School, FAE University Center, Curitiba, Paraná, Brazil. International University UNINTER, Curitiba, Paraná, Brazil.

ORCID: https://orcid.org/0000-0003-4896-4960.

This study was financed in part by the Coordenação de Aperfeiçoamento de Pessoal de Nível Superior - Brasil (CAPES) - Finance Code 001; and another part by Fundação Araucária de Apoio ao Desenvolvimento Científico e Tecnológico do Estado do Paraná (FA).

\section{About the article}

Submission received on March 17, 2018. Approved for publication on February 21, 2019. 